\title{
ANALISIS OVERALL EQUIPMENT EFFECTIVENESS (OEE) MESIN PRODUKSI PADA PT. INDOFOOD CBP SUKSES MAKMUR TbK MAKASSAR
}

\author{
Muhammad Arsyad ${ }^{1}$, Arthur Halik Razak ${ }^{1}$, Sumardi Mawardi ${ }^{2}$, Fadli Abdul Azis ${ }^{2}$
}

\begin{abstract}
Abstrak: Dalam dunia industri, efisiensi sangat dibutuhkan untuk mencapai keuntungan yang setinggi-tingginya. Berbagai cara dilaksanakan untuk mencapai efisiensi yang diinginkan, termasuk dengan melaksanakan Total Productive Maintenance (TPM). Untuk mengetahui sejauh mana efisiensi yang telah dilakukan pada PT. INDOFOOD CBP SUKSES MAKMUR Tbk (divisi noddle - pabrik makassar), dapat dilakukan dengan menghitung Overall Equipment Effectitiness (OEE). OEE diukur melalui availability, performance efficiency dan rate of quality product, kemudian di rincikan kembali pada analisa six big losses. Dari hasil analisa menunjukkan bahwa PT. INDOFOOD CBP SUKSES MAKMUR Tbk (divisi noddle - pabrik makassar), berada diatas standar global OEE sebesar 85\% (Nakajima,1988).
\end{abstract}

Kata kunci: Atap tumbuhan, Konsumsi energi tahunan, Penghematan energi, TRNSYS17.

\section{PENDAHULUAN}

PT. INDOFOOD CBP SUKSES MAKMUR Tbk (divisi noddle - pabrik makassar) merupakan perusahaan yang bergerak dalam produksi mie instant. Pada proses produksinya, mesin-mesin produksi tergabung dalam satu unit yang disebut lini produksi dan sudah dilengkapi proses otomasi untuk meningkatkan hasil produksi yang maksimal secara konsisten. Menurut Pentilon dan Muchiri (2006) usaha meningkatkan produktivitas dalam menghadapi persaingan global saat ini telah memunculkan kesadaran bahwa dibutuhkannya pengukuran performa proses produksi yang tepat.

Pertanyaan selanjutnya adalah "bagaimana sebuah perusahaan mengoptimalkan prestasi pada mesin/peralatan yang sudah ada?". Jawabannya adalah Overall Equipment Effectiveness (OEE). OEE adalah pedoman untuk sebagai bahan acuan, menganalisa dan meningkatkan proses produksi. OEE memberikan kemampuan untuk mengukur kinerja mesin untuk pengembangan produktivitas. OEE dijabarkan dalam tiga bagian pengukuran yaitu Availability, Performance, dan Quality. Nakajima (1988) mengatakan bahwa standar kelas dunia untuk nilai OEE adalah sebesar 85\% dengan standar nilai availability $90 \%$, nilai performance rate $95 \%$, dan nilai quality rate $99,9 \%$.

"It has been found that in the UK manufacturing industry, maintenance spending accounts for a significant 12 to 23 percent of the total factory operating costs" (Cross, 1988). Setelah diketahui nilai efisiensi mesin/peralatan maka diperlukan langkah untuk meningkatkan atau mempertahankan nilai efisiensi tersebut, cara yang paling banyak dilakukan adalah menggunakan sistem Total Productive Maintenance (TPM). TPM didefinisikan sebagai konsep perbaikan berkelanjutan yang melibatkan seluruh karyawan untuk meningkatkan perawatan mesin, peralatan, dan meningkatkan produktivitas. Indikator kesuksesan TPM di ukur oleh OEE (Overall Equipment Effectiveness) dimana ukuran kinerja ini mencakup ke berbagai macam kerugian (losses) seperti downtime, setup, speed loss, idle mesin, stoppages, defect, dan rework. "Total productive maintenance is an innovative approach to maintenance that optimizes equipment effectiveness, eliminates breakdowns and promotes autonomous maintenance by operators through day-to-day activities involving total workforce" (Bhadury, 2000).

Penelitian ini dilakukan untuk mendapatkan gambaran tentang kesesuaian faktor-faktor yang menentukan kebutuhan penerapan total productive maintenance dengan kondisi perusahaan dan melihat faktor mana dari six big losses tersebut yang dominan mempengaruhi terjadinya penurunan efektivitas mesin/peralatan. Dengan demikian penulisan ini akan memberikan usulan perbaikan

\footnotetext{
${ }^{1}$ Staf Pengajar D4 Jurusan Teknik Mesin Politeknik Negeri Ujung Pandang

${ }^{2}$ Alumni Jurusan Teknik Mesin Politeknik Negeri Ujung Pandang
}

DOI : $\underline{\text { http://dx.doi.org/10.31963/sinergi.v16i1.1198 }}$ 
11 Muhammad Arsyad, Arthur Halik Razak, Sumardi Mawardi, Fadli Abdul Azis. Analisis Overall Equipment Effectiveness (Oee) Mesin Produksi Pada Pt. Indofood Cbp Sukses Makmur Tbk Makassar

efektivitas mesin/peralatan dalam usaha meningkatkan efisiensi produksi pada perusahaan melalui analisa OEE

\section{METODOLOGI PENELITIAN}

Langkah-langkah penelitian dan blok diagram perhitungan overall equipment effectiveness ini dapat dilihat pada gambar 1.

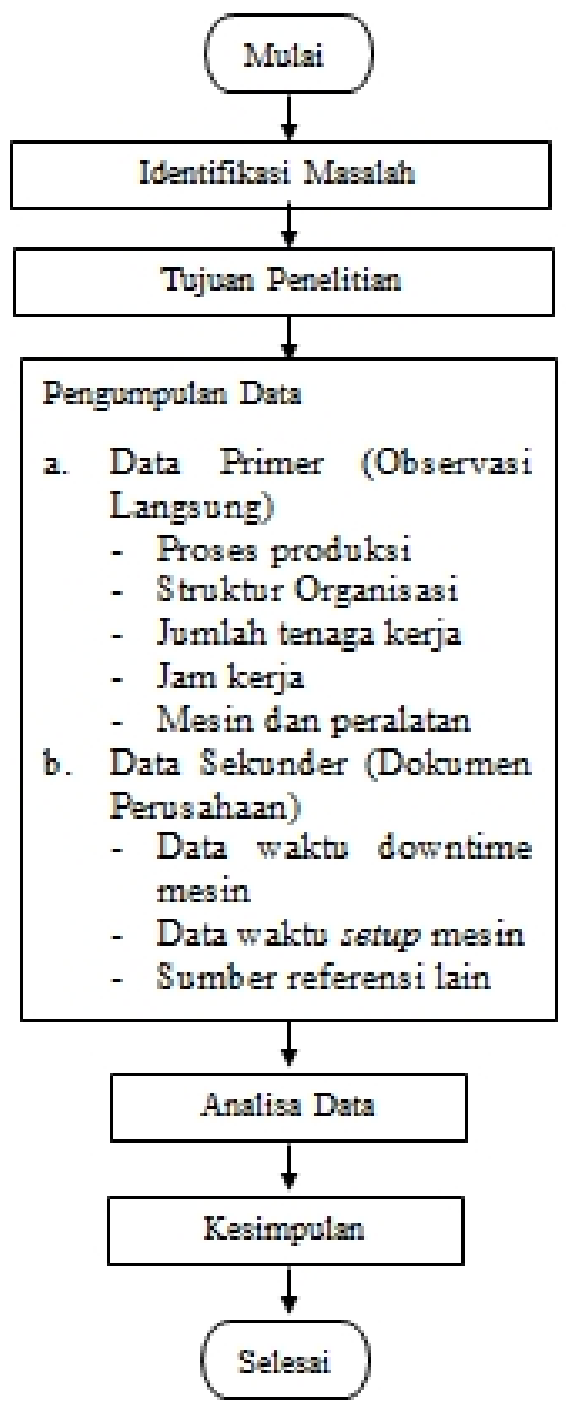

Gambar 1. Tahapan Proses Pemecahan Masalah

\section{HASIL DAN PEMBAHASAN}

A. Hasil

1. Perhitungan OEE

Penentuan nilai OEE dilakukan dengan menggunakan beberapa data penunjang seperti operating time, cycle time, loading time, downtime, process amount, dan defect amount dari mesin. Data-data disajikan pada Tabel 1, 2, 3. 
Tabel 1. Data performance tahun 2012

\begin{tabular}{|c|r|r|r|r|r|r|r|}
\hline & $\begin{array}{c}\text { Down } \\
\text { Time } \\
\text { Mesin }\end{array}$ & $\begin{array}{c}\text { Down } \\
\text { Time } \\
\text { Lain }\end{array}$ & $\begin{array}{c}\text { Loading } \\
\text { Time }\end{array}$ & $\begin{array}{c}\text { standar } \\
\text { output }\end{array}$ & $\begin{array}{c}\text { actual } \\
\text { output }\end{array}$ & $\begin{array}{c}\text { Defect } \\
\text { Ammount } \\
\text { (Scrap) }\end{array}$ & Set Up \\
\hline Line 1 & 10.82 & 37.21 & $5,339.86$ & $2,248,169$ & $2,277,173$ & $27,098.36$ & 1.13 \\
\hline Line 2 & 24.43 & 119.95 & $4,404.27$ & $1,825,290$ & $1,795,691$ & $24,960.10$ & 2.90 \\
\hline Line 3 & 11.77 & 29.77 & $1,516.19$ & 667,058 & 661,900 & $9,398.98$ & 1.37 \\
\hline Line 6 & 22.97 & 48.61 & $5,365.85$ & $2,754,412$ & $2,772,765$ & $31,886.80$ & 2.36 \\
\hline Line 7 & 33.81 & 61.19 & $5,545.31$ & $2,799,999$ & $2,797,337$ & $30,211.24$ & 3.11 \\
\hline Line 8 & 17.16 & 53.53 & $4,657.27$ & $2,371,071$ & $2,369,910$ & $26,542.99$ & 1.72 \\
\hline Line 9 & 30.14 & 90.90 & $4,559.64$ & $2,289,694$ & $2,290,434$ & $26,110.95$ & 3.12 \\
\hline
\end{tabular}

Tabel 2. Data performance tahun 2013

\begin{tabular}{|c|r|r|r|c|c|c|c|}
\hline & $\begin{array}{c}\text { Down } \\
\text { Time } \\
\text { Mesin }\end{array}$ & $\begin{array}{c}\text { Down } \\
\text { Time } \\
\text { Lain }\end{array}$ & $\begin{array}{c}\text { Loading } \\
\text { Time }\end{array}$ & $\begin{array}{c}\text { standar } \\
\text { output }\end{array}$ & $\begin{array}{c}\text { actual } \\
\text { output }\end{array}$ & $\begin{array}{c}\text { Defect } \\
\text { Ammount } \\
\text { (Scrap) }\end{array}$ & Set Up \\
\cline { 2 - 7 } & (hour) & (hour) & (pcs) & (pcs) & (pcs) & (hour) \\
\hline Line 1 & 226.28 & 7.10 & $6,498.80$ & $2,584,478$ & $2,592,485$ & $20,999.13$ & 23.83 \\
\hline Line 2 & 305.22 & 70.10 & $6,562.77$ & $2,508,351$ & $2,515,735$ & $20,629.03$ & 28.69 \\
\hline Line 3 & 347.92 & 24.65 & $4,375.94$ & $1,619,177$ & $1,587,599$ & $13,494.59$ & 29.92 \\
\hline Line 6 & 429.00 & 24.29 & $5,718.50$ & $2,533,358$ & $2,514,871$ & $21,879.38$ & 44.02 \\
\hline Line 8 & 341.58 & 8.74 & $6,381.08$ & $2,966,602$ & $2,952,535$ & $22,734.52$ & 31.43 \\
\hline Line 9 & 429.03 & 22.44 & $5,646.03$ & $2,483,338$ & $2,462,301$ & $21,422.02$ & 44.36 \\
\hline
\end{tabular}

Tabel 3. Data performance tahun 2014

\begin{tabular}{|c|r|r|r|r|r|r|r|} 
& $\begin{array}{c}\text { Down } \\
\text { Time } \\
\text { Mesin }\end{array}$ & $\begin{array}{c}\text { Down } \\
\text { Time } \\
\text { Lain }\end{array}$ & $\begin{array}{c}\text { Loading } \\
\text { Time }\end{array}$ & $\begin{array}{c}\text { standar } \\
\text { output }\end{array}$ & $\begin{array}{c}\text { actual } \\
\text { output }\end{array}$ & $\begin{array}{c}\text { Defect } \\
\text { Ammount } \\
\text { (Scrap) }\end{array}$ & Set Up \\
\hline Line 1 & 25.16 & 8.00 & $6,180.19$ & $2,599,204$ & $2,593,664$ & $70,807.03$ & 648.12 \\
\hline Line 2 & 44.34 & 33.63 & $6,176.43$ & $2,594,871$ & $2,596,552$ & $62,836.56$ & 576.42 \\
\hline Line 3 & 17.44 & 1.83 & $1,134.94$ & 497,680 & 487,921 & $12,441.99$ & 96.11 \\
\hline Line 6 & 39.02 & 7.00 & $5,938.02$ & $1,068,264$ & $1,067,500$ & $16,439.50$ & 605.24 \\
\hline Line 7 & 58.90 & 7.00 & $5,856.40$ & $1,111,063$ & $1,119,142$ & $19,808.81$ & 533.37 \\
\hline Line 8 & 57.84 & 9.88 & $5,972.84$ & $1,005,718$ & $1,005,120$ & $19,298.30$ & 592.09 \\
\hline Line 9 & 190.53 & 14.47 & $6,117.53$ & $1,068,319$ & $1,077,645$ & $28,342.06$ & 612.85 \\
\hline
\end{tabular}

Berdasarkan persamaan 1, maka yang terlebih dahulu kita menghitung availability, performance efficiency dan rate of quality, sampel perhitungan yang digunakan adalah lini 1 pada tahun 2012. 
13 Muhammad Arsyad, Arthur Halik Razak, Sumardi Mawardi, Fadli Abdul Azis. Analisis Overall Equipment Effectiveness (Oee) Mesin Produksi Pada Pt. Indofood Cbp Sukses Makmur Tbk Makassar

\begin{tabular}{|c|c|c|c|c|c|c|c|}
\hline & $\begin{array}{c}\text { Down } \\
\text { Time } \\
\text { Mesin }\end{array}$ & $\begin{array}{c}\text { Down } \\
\text { Time } \\
\text { Lain }\end{array}$ & $\begin{array}{c}\text { Loading } \\
\text { Time }\end{array}$ & $\begin{array}{c}\text { standar } \\
\text { output }\end{array}$ & $\begin{array}{c}\text { actual } \\
\text { output }\end{array}$ & $\begin{array}{c}\text { Defect } \\
\text { Ammount } \\
\text { (Scrap) }\end{array}$ & Set Up \\
\cline { 2 - 8 } & (hour) & (hour) & (hour) & (pcs) & (pcs) & (pcs) & (hour) \\
\hline Line 1 & 10.82 & 37.21 & $5,339.86$ & $2,248,169$ & $2,277,173$ & $27,098.36$ & 1.13 \\
\hline
\end{tabular}

Jadi Perhitungannya adalah:

a. Availability

Nilai availability dihitung dengan rumus sebagai berikut :

$$
\begin{aligned}
& A_{v}=\frac{l_{t}-d_{t}}{l_{t}} \times 100 \%=\frac{o_{t}}{l_{t}} \times 100 \% \ldots \ldots \ldots \ldots \ldots \ldots \ldots \\
& A_{v}=\frac{5339.86-10.82}{5339.86} \times 100 \%=\frac{5329.04}{5339.86} \times 100 \% \\
& A_{v}=99,8 \%
\end{aligned}
$$

Jadi nilai Availability lini 1 pada tahun 2012 adalah sebesar 99,8\%.

b. Performance Efficiency

Perfomance efficiency dapat dihitung sebagai berikut :

$$
\begin{aligned}
P_{E} & =\frac{P_{A} \times i_{C}}{o_{t}} \times 100 \% \ldots \ldots \ldots \ldots \ldots \ldots \ldots \ldots \ldots \ldots \ldots \ldots \ldots \ldots \ldots \ldots \ldots \ldots \ldots \ldots \ldots \\
i_{c} & =\frac{l_{t}}{P_{A}} \ldots \ldots \ldots \ldots \ldots \ldots \\
i_{c} & =\frac{5339,86}{2248169} \\
i_{c} & =0.002375 \\
P_{E} & =\frac{2277173 \times 0,002375}{5339,86} \times 100 \% \\
P_{E} & =\frac{5408.285875}{5339.86} \times 100 \% \\
P_{E} & =101,2 \%
\end{aligned}
$$

Jadi nilai Perfomance efficiency lini 1 pada tahun 2012 adalah sebesar 101,2\%.

c. Rate of Quality

Rate of quality product dapat dihitung sebagai berikut :

$$
\begin{aligned}
R_{Q} & =\frac{P_{A}-D_{A}}{P_{A}} \times 100 \% \ldots \ldots \ldots \ldots \ldots \ldots \\
R_{Q} & =\frac{2277173-27098,36}{2248169} \times 100 \% \\
R_{Q} & =\frac{2250074,64}{2277173} \times 100 \% \\
R_{Q} & =98,81 \%
\end{aligned}
$$

Jadi nilai Rate of quality lini 1 pada tahun 2012 adalah sebesar 98,81\%.

Formula matematis dari overall equipment effectiveness (OEE) dirumuskan sebagai berikut :

$$
\begin{aligned}
O & =A_{v} \times P_{E} \times R_{Q} \times 100 \% \ldots \ldots \ldots \ldots \ldots \ldots \\
O & =0,998 \times 1,012 \times 0,9881 \times 100 \% \\
O & =99,8 \%
\end{aligned}
$$

Jadi nilai OEE lini 1 pada tahun 2012 adalah sebesar $99.8 \%$.

Berikut hasil perhitungan OEE setiap lini produksi pada tahun 2012-2014: 
Tabel 5. Nilai OEE tahun 2012

\begin{tabular}{l|r|r|r|r|}
\hline & Availability (\%) & Performance Eficiency (\%) & Rate Of Quality (\%) & OEE (\%) \\
\hline Line 1 & 99.80 & 101.29 & 98.81 & 99.88 \\
\hline Line 2 & 99.45 & 98.38 & 98.61 & 96.47 \\
\hline Line 3 & 99.22 & 99.23 & 98.58 & 97.06 \\
\hline Line 6 & 99.57 & 100.67 & 98.85 & 99.08 \\
\hline Line 7 & 99.39 & 99.90 & 98.92 & 98.22 \\
\hline Line 8 & 99.63 & 99.95 & 98.88 & 98.47 \\
\hline Line 9 & 99.34 & 100.03 & 98.86 & 98.24 \\
\hline Rata-rata & 99.49 & 99.92 & 98.79 & 98.20 \\
\hline
\end{tabular}

Tabel 6. Nilai OEE tahun 2013

\begin{tabular}{l|r|r|r|r|}
\hline & Availability (\%) & Performance Eficiency (\%) & Rate Of Quality (\%) & OEE (\%) \\
\hline Line 1 & 96.52 & 100.31 & 99.19 & 96.03 \\
\hline Line 2 & 95.35 & 100.29 & 99.18 & 94.85 \\
\hline Line 3 & 92.05 & 98.05 & 99.15 & 89.49 \\
\hline Line 6 & 92.50 & 99.27 & 99.13 & 91.02 \\
\hline Line 7 & 94.65 & 99.53 & 99.23 & 93.47 \\
\hline Line 8 & 95.92 & 100.48 & 99.25 & 95.66 \\
\hline Line 9 & 92.40 & 99.15 & 99.13 & 90.82 \\
\hline Rata-rata & 94.20 & 99.58 & 99.18 & 93.05 \\
\hline
\end{tabular}

Tabel 7. Nilai OEE tahun 2014

\begin{tabular}{l|r|r|r|r|} 
& Availability (\%) & Performance Eficiency (\%) & Rate Of Quality (\%) & OEE (\%) \\
\hline Line 1 & 99.59 & 99.79 & 97.27 & 96.67 \\
\hline Line 2 & 99.28 & 100.06 & 97.58 & 96.94 \\
\hline Line 3 & 98.46 & 98.04 & 97.45 & 94.07 \\
\hline Line 6 & 99.34 & 99.93 & 98.46 & 97.74 \\
\hline Line 7 & 98.99 & 100.73 & 98.23 & 97.95 \\
\hline Line 8 & 99.03 & 99.94 & 98.08 & 97.07 \\
\hline Line 9 & 96.89 & 100.87 & 97.37 & 95.16 \\
\hline Rata-rata & 98.80 & 99.91 & 97.78 & 96.52 \\
\hline
\end{tabular}

2. Perhitungan Six Big Losses

Perhitungan ini mengambil sampel lini produksi 1 pada tahun 2012

a. Perhitungan Downtime Losses

1) Perhitungan Equipment Failures (Breakdowns)

Kegagalan mesin melakukan proses (equipment failure) atau kerusakan (breakdown) yang tiba-tiba dan tidak diharapkan terjadi adalah penyebab kerugian yang terlihat jelas, karena kerusakan tersebut akan mengakibatkan mesin tidak menghasilkan output.

Besarnya persentase efektivitas mesin yang hilang akibat faktor breakdowns loss dapat dihitung dengan menggunakan rumusan sebagai berikut :

$$
\begin{array}{rrrl}
B & =\frac{T b}{l_{t}} \times 100 \% \ldots \ldots \ldots \ldots \ldots \ldots \ldots \ldots \ldots \ldots \ldots
\end{array}
$$


15 Muhammad Arsyad, Arthur Halik Razak, Sumardi Mawardi, Fadli Abdul Azis. Analisis Overall Equipment Effectiveness (Oee) Mesin Produksi Pada Pt. Indofood Cbp Sukses Makmur Tbk Makassar

$$
\begin{array}{lll}
B & L & =\frac{10,82-1,14}{5339,86} \times 100 \% \\
B & L & =\frac{9,68}{5339,86} \times 100 \% \\
B & L & =0,18 \%
\end{array}
$$

Jadi nilai breakdowns losslini 1 pada tahun 2012 adalah sebesar $0,18 \%$.

2) Perhitungan Setup dan Adjustment

Kerusakan pada mesin maupun pemeliharaan mesin secara keseluruhan akan mengakibatkan mesin tersebut harus dihentikan terlebih dahulu. Sebelum mesin difungsikan kembali akan dilakukan penyesuaian terhadap fungsi mesin tersebut yang dinamakan dengan waktu setup dan adjustment mesin. Untuk mengetahui besarnya persentase downtime loss yang diakibatkan oleh waktu setup andadjustment tersebut digunakan rumusan sebagai berikut:

$$
\begin{aligned}
& S=\frac{T s}{l_{t}} \times 100 \% \\
& S \quad a \quad a \\
& L=\frac{T \quad S \quad T i}{L} \times 100 \% \\
& S \quad a \quad a \\
& L=\frac{1,14}{5339,86} \times 100 \% \\
& S \quad a \quad a c \\
& L \quad=0,021 \%
\end{aligned}
$$

Jadi nilai Setup and adjustment loss lini 1 pada tahun 2012 adalah sebesar 0,021\%.

b. Perhitungan Speed Loss

Speed loss terjadi pada saat mesin tidak beroperasi sesuai dengan kecepatan produksi maksimum yang sesuai dengan kecepatan mesin yang dirancang. Faktor yang mempengaruhi speed losses ini adalah idling and minor stoppages dan reduced speed.

1) PerhitunganIdling dan Minor Stoppages

Idling dan minor stoppages terjadi jika mesin berhenti secara berulang-ulang atau mesin beroperasi tanpa menghasilkan produk. Jika idling dan minor stoppages sering terjadi maka dapat mengurangi efektivitas mesin.Untuk mengetahui besarnya faktor efektivitas yang hilang karena faktor idling andminor stoppages digunakan rumusan sebagai berikut :

$$
\begin{aligned}
& \text { I } \quad=\frac{N}{l_{t}} \times 100 \% \\
& \text { ic } \quad a \quad m \quad s \\
& =\frac{N \quad p r \quad t i}{L} \times 100 \% \\
& \text { ic } \quad a \quad m \quad s t
\end{aligned}
$$

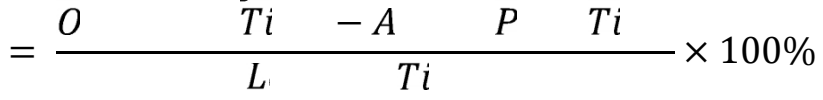

$$
\begin{aligned}
& \text { ic } \quad a \quad m \quad s \\
& =\frac{5329,04-5281,01}{5339.86} \times 100 \% \\
& \text { ic } \quad a \quad m \quad s \\
& =\frac{48,03}{5339.86} \times 100 \% \\
& \text { ic } \quad a \quad m \quad s \\
& =0,90 \%
\end{aligned}
$$

2) Perhitungan Reduced Speed

Reduced speed adalah selisih antara waktu kecepatan produksi aktual dengan kecepatan produksi mesin yang ideal. Untuk mengetahui besarnya persentase faktor reduced speed yang hilang, maka digunakan rumusan berikut : 


$$
\begin{aligned}
& R=\frac{(i \times T \quad)-l_{i}}{l_{t}} \times 100 \% \ldots \ldots \ldots \ldots \ldots \ldots \ldots \\
& R \quad S \quad L=\frac{(0,002375 \times 2277173)-5339,86}{5339,86} \times 100 \% \\
& R \quad S \quad L \quad=\frac{5408,75-5339,86}{5339,86} \times 100 \% \\
& R \quad S \quad L \quad=\frac{68,89}{5339,86} \times 100 \% \\
& R \quad S \quad L=1,29 \%
\end{aligned}
$$

Jadi nilai reduced speed losslini 1 pada tahun 2012 adalah sebesar $\quad 1,29 \%$.

c. Perhitungan Defect Loss

Defect loss artinya adalah mesin tidak menghasilkan produk yang sesuai dengan spesifikasi dan standar kualitas produk yang telah ditentukan dan scrap sisa hasil proses selama produksi berjalan. Faktor yang dikategorikan ke dalam defect loss adalah rework loss dan yield/scrap loss.

1) Perhitungan Rework Loss

Tidak ada rework pada lini produksi

2) Perhitungan Yield/Scrap Loss

Yield/scrap loss adalah kerugian yang timbul selama proses produksi belum mencapai keadaan produksi yang stabil pada saat proses produksi mulai dilakukan sampai tercapainya keadaan proses yang stabil, sehingga produk yang dihasilkan pada awal proses sampai keadaan proses stabil dicapai tidak memenuhi spesifikasi kualitas yang diharapkan.Untuk mengetahui persentase factor yield/scrap loss yang mempengaruhi efektivitas penggunaan mesin. digunakan rumusan sebagai berikut :

$$
\begin{aligned}
& S=\frac{i \times S}{l_{t}} \times 100 \% \text {. } \\
& S a l=\frac{0,002375 \times 27098, .36}{5339,86} \times 100 \% \\
& S \quad l c=\frac{64,358605}{5339,86} \times 100 \% \\
& S \quad l c=1,21 \%
\end{aligned}
$$

Jadi nilai scrap losslini 1 pada tahun 2012 adalah sebesar 1,21\%.

Tabel 8. Nilai six big losses tahun 2012

\begin{tabular}{|l|r|r|r|r|r|r|}
\hline \multirow{2}{*}{$\begin{array}{c}\text { Six big } \\
\text { losses }\end{array}$} & $\begin{array}{c}\text { Equipment } \\
\text { failures }\end{array}$ & $\begin{array}{c}\text { Setup and } \\
\text { Adjusment }\end{array}$ & $\begin{array}{c}\text { Iddling and } \\
\text { minor } \\
\text { stoppages }\end{array}$ & $\begin{array}{c}\text { Reduced } \\
\text { Speed }\end{array}$ & $\begin{array}{c}\text { Rework } \\
\text { Loss }\end{array}$ & $\begin{array}{c}\text { Scrap } \\
\text { Loss }\end{array}$ \\
\cline { 2 - 7 } & \multicolumn{1}{c|}{$(\%)$} & \multicolumn{1}{c}{$(\%)$} & \multicolumn{1}{c|}{$(\%)$} & \multicolumn{1}{c}{$(\%)$} & \multicolumn{1}{c|}{$(\%)$} \\
\hline Line 1 & 0.18 & 0.02 & 1.10 & 1.29 & 0.00 & 1.21 \\
\hline Line 2 & 3.28 & 0.07 & 3.83 & 1.62 & 0.00 & 1.37 \\
\hline Line 3 & 2.74 & 0.09 & 3.52 & 0.77 & 0.00 & 1.41 \\
\hline Line 5 & 3.34 & 0.21 & 4.72 & 5.15 & 0.00 & 1.90 \\
\hline Line 6 & 1.33 & 0.04 & 1.76 & 0.67 & 0.00 & 1.16 \\
\hline Line 7 & 1.71 & 0.06 & 2.32 & 0.10 & 0.00 & 1.08 \\
\hline Line 8 & 1.52 & 0.04 & 1.89 & 0.05 & 0.00 & 1.12 \\
\hline Line 9 & 2.65 & 0.07 & 3.32 & 0.03 & 0.00 & 1.14 \\
\hline
\end{tabular}


17 Muhammad Arsyad, Arthur Halik Razak, Sumardi Mawardi, Fadli Abdul Azis. Analisis Overall Equipment Effectiveness (Oee) Mesin Produksi Pada Pt. Indofood Cbp Sukses Makmur Tbk Makassar

Tabel 9. Nilai six big losses tahun 2013

\begin{tabular}{|l|r|r|r|r|r|r|}
\hline \multirow{2}{*}{$\begin{array}{c}\text { Six big } \\
\text { losses }\end{array}$} & $\begin{array}{c}\text { Equipment } \\
\text { failures }\end{array}$ & $\begin{array}{c}\text { Setup and } \\
\text { Adjusment }\end{array}$ & $\begin{array}{c}\text { Iddling and } \\
\text { minor } \\
\text { stoppages }\end{array}$ & $\begin{array}{c}\text { Reduced } \\
\text { Speed }\end{array}$ & $\begin{array}{c}\text { Rework } \\
\text { Loss }\end{array}$ & $\begin{array}{c}\text { Scrap } \\
\text { Loss }\end{array}$ \\
\cline { 2 - 7 } & \multicolumn{1}{c|}{$(\%)$} & $(\%)$ & $(\%)$ & $(\%)$ & \multicolumn{1}{c|}{$(\%)$} \\
\hline Line 1 & 3.12 & 0.37 & 7.07 & 0.31 & 0 & 0.81 \\
\hline Line 2 & 5.72 & 0.44 & 10.37 & 0.29 & 0 & 0.82 \\
\hline Line 3 & 8.51 & 0.68 & 16.46 & 1.95 & 0 & 0.83 \\
\hline Line 6 & 7.93 & 0.77 & 15.43 & 0.73 & 0 & 0.86 \\
\hline Line 7 & 5.49 & 0.49 & 10.84 & 0.47 & 0 & 0.77 \\
\hline Line 8 & 4.31 & 0.41 & 8.39 & 0.48 & 0 & 0.75 \\
\hline Line 9 & 8.00 & 0.79 & 15.60 & 0.85 & 0 & 0.86 \\
\hline
\end{tabular}

Tabel 10. Nilai six big losses tahun 2014

\begin{tabular}{|l|r|r|r|r|r|r|}
\multirow{2}{*}{$\begin{array}{c}\text { Six big } \\
\text { losses }\end{array}$} & $\begin{array}{c}\text { Equipment } \\
\text { failures }\end{array}$ & $\begin{array}{c}\text { Setup and } \\
\text { Adjusment }\end{array}$ & $\begin{array}{c}\text { Iddling and } \\
\text { minor } \\
\text { stoppages }\end{array}$ & $\begin{array}{c}\text { Reduced } \\
\text { Speed }\end{array}$ & $\begin{array}{c}\text { Rework } \\
\text { Loss }\end{array}$ & $\begin{array}{c}\text { Scrap } \\
\text { Loss }\end{array}$ \\
\cline { 2 - 7 } & $(\%)$ & $(\%)$ & $(\%)$ & $(\%)$ & $(\%)$ & \multicolumn{1}{c|}{$(\%)$} \\
\hline Line 1 & 0.36 & 0.04 & 0.94 & 0.21 & 0 & 2.72 \\
\hline Line 2 & 1.26 & 0.07 & 1.98 & 0.06 & 0 & 2.42 \\
\hline Line 3 & 1.70 & 0.13 & 3.23 & 1.96 & 0 & 2.50 \\
\hline Line 6 & 0.78 & 0.07 & 1.43 & 0.07 & 0 & 1.54 \\
\hline Line 7 & 1.13 & 0.09 & 2.13 & 0.73 & 0 & 1.78 \\
\hline Line 8 & 1.13 & 0.10 & 2.10 & 0.06 & 0 & 1.92 \\
\hline Line 9 & 3.35 & 0.32 & 6.47 & 0.87 & 0 & 2.65 \\
\hline
\end{tabular}

B. Pembahasan

1. Analisa OEE

Dari hasil perhitungan nilai OEE di dapatkan tabel seperti pada tabel 5, tabel 6, dan tabel 7 . Menurut Nakajima (1988) mengatakan bahwa standar kelas dunia untuk nilai OEE adalah sebesar $85 \%$ dengan standar nilai availability $90 \%$, nilai Performance Efficiency $95 \%$, dan nilai Rate of Quality 99,9\%.

Sebagai contoh: lini produksi 1 (line 1) pertahun secara spesifik diperlihatkan pada Gambar 2, 3, 4. Sedangkan nilai OEE-nya diperlihatkan pada Gambar 5.

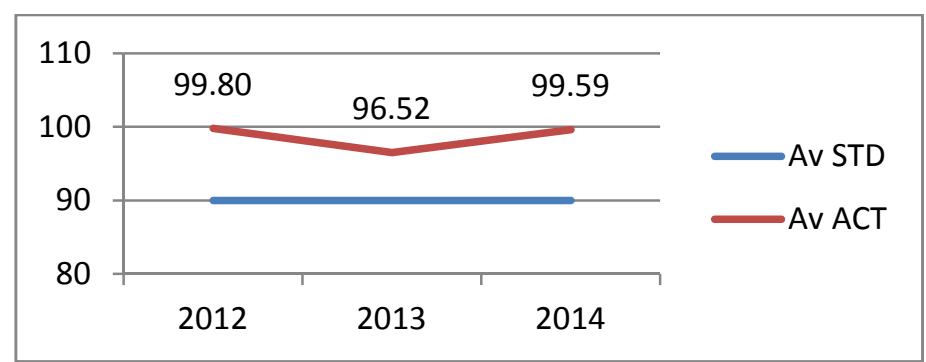

Gambar 2. Diagram availability lini produksi 1 dan nilai standar availability standar global (Nakajima) 


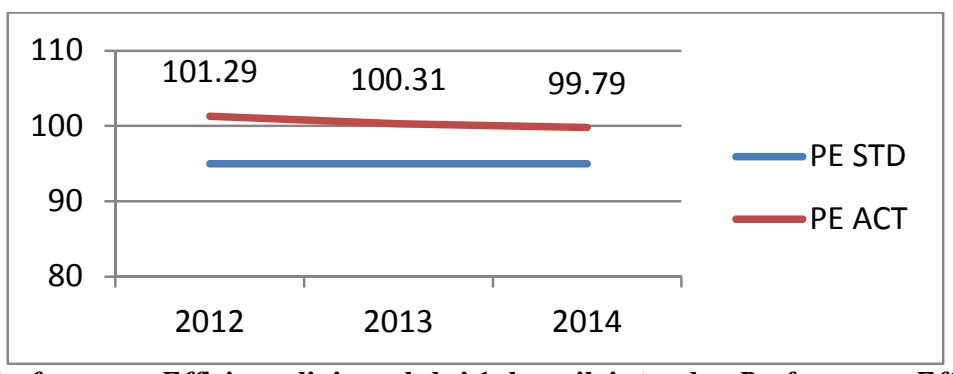

Gambar 3. Diagram Performance Efficiency lini produksi 1 dan nilai standar Performance Efficiency standar global (Nakajima)

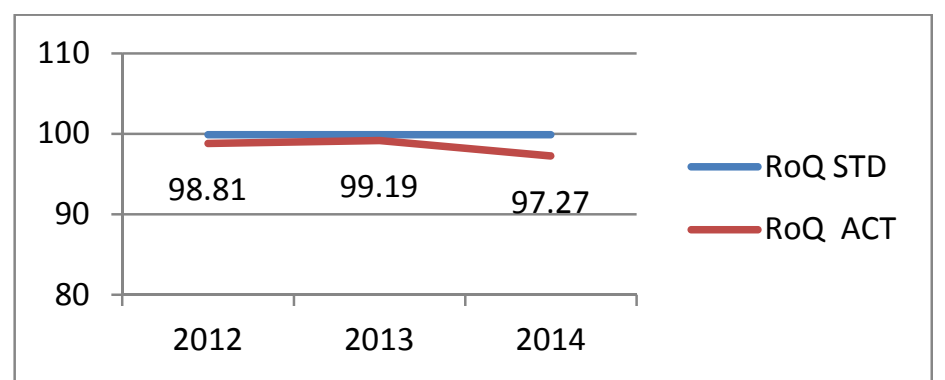

Gambar 4. Diagram Rate of Quality lini produksi 1 dan nilai standar Rate of Quality standar global (Nakajima)

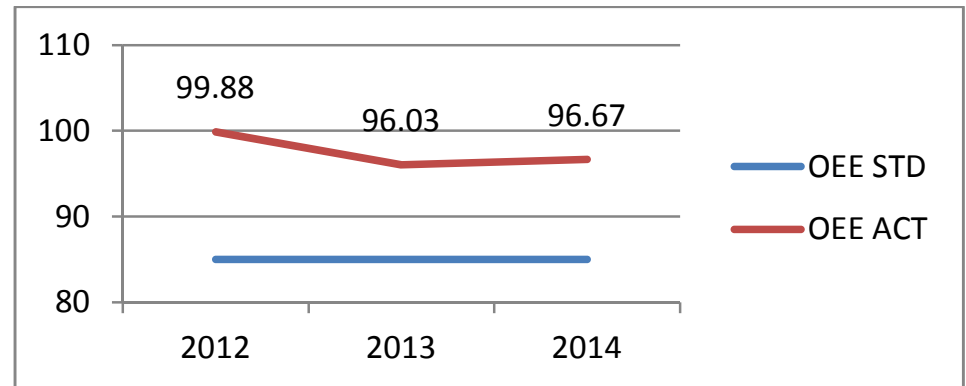

Gambar 5. Diagram OEE lini produksi 1 dan nilai standar OEE standar global (Nakajima)

Pada Gambar 2, 3, 4, dan 5, garis warna merah menunjukkan nilai aktual, sedangkan garis warna biru menunjukkan nilai standar (Nakajima,1988). Sebagaimana yang diperlihatkan pada gambar-gambar tersebut, hanya Gambar 5 yang menunjukkan nilai aktual dibawah nilai standar. Hal ini dipengaruhi oleh adanya nilai scrap(hasil produksi rusak)yang terjadi pada proses produksi. Semakin besar nilai scrap maka nilai actual rate of quality-nya, semakin di bawah nilai standar.

Dari hasil perhitungan maka nilai availabilitytiap line per tahun diperlihatkan pada Gambar 6, 7,8 . 
19 Muhammad Arsyad, Arthur Halik Razak, Sumardi Mawardi, Fadli Abdul Azis. Analisis Overall Equipment Effectiveness (Oee) Mesin Produksi Pada Pt. Indofood Cbp Sukses Makmur Tbk Makassar

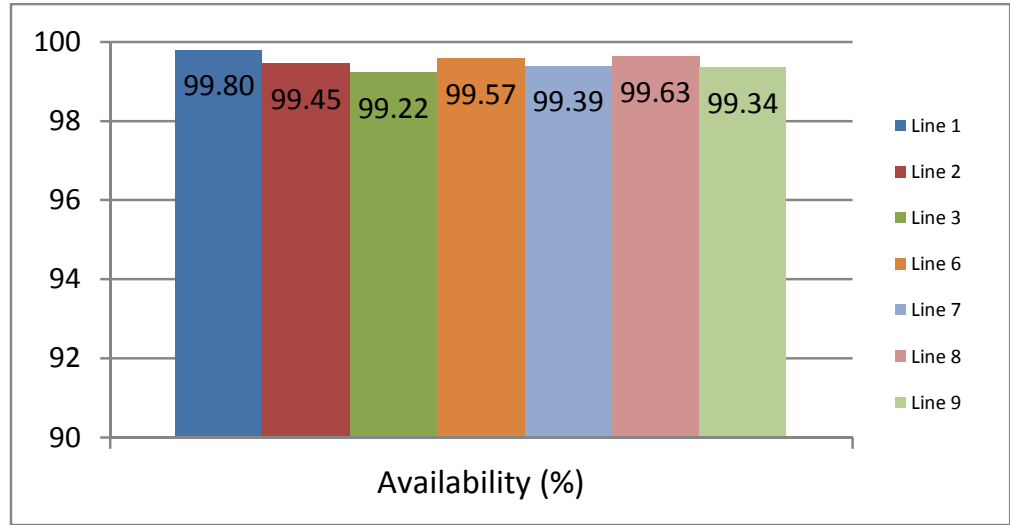

Gambar 6. Diagram availabilitylini produksi pada tahun 2012

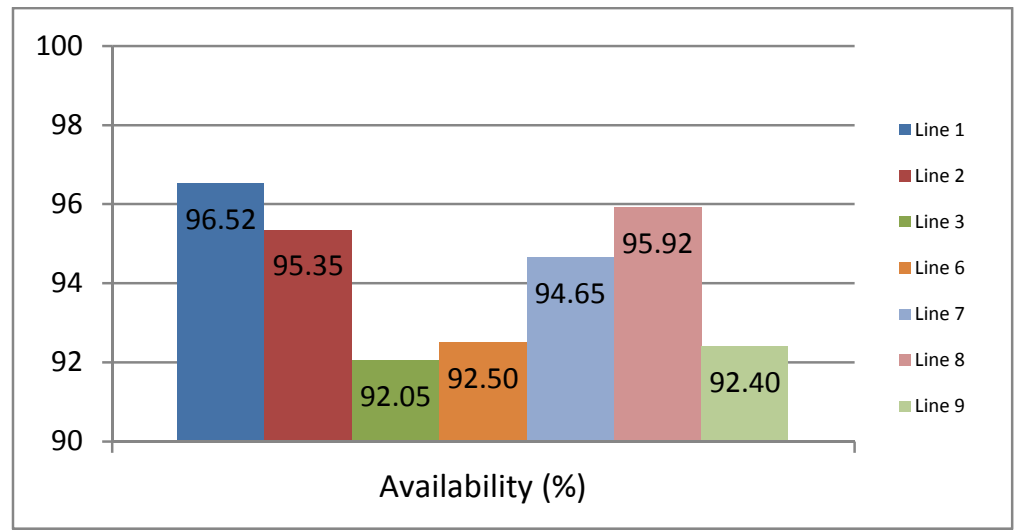

Gambar 7. Diagram availabilitylini produksi pada tahun 2013

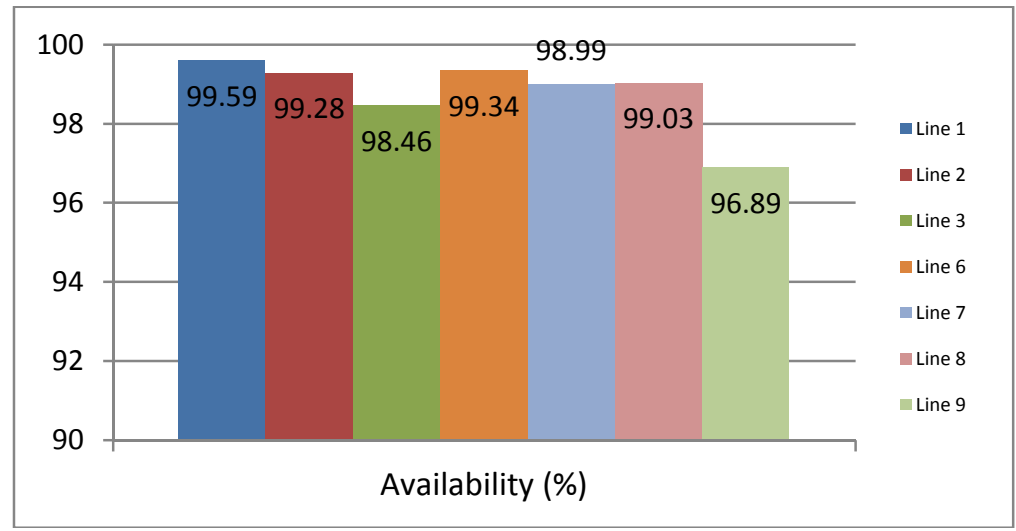

Gambar 8. Diagram availability lini produksi pada tahun 2014

Berdasarkan Gambar 6, 7, 8, nilai availabilitysetiap lini produksi telah memenuhi standar yang telah ditentukan oleh Nakajima(1988), yaitu 90\%, dengan kisaran antara 92.05\% (Gambar 6) sampai dengan 99.8\% (Gambar 8). Dengan nilai persentase down time yang diijinkan sebesar $1.5 \%$, sebagian besar lini produksi melampaui standar tersebut. Besarnya nilai totaldown timemesin suatu lini produksi mempengaruhi nilai availability dari lini produksi tersebut. Ini terlihat pada tahun 2013 dimana seluruh lini produksi memiliki totaldown timemesin yang melebihi standar yang ditetapkan, sehingga menyebabkan nilai availability menjadi rendah dibanding tahun yang lainnya. Jadi, semakin besar nilai totaldown timemesin dari lini produksi, maka akan semakin menurunkan nilai availability-nya. Secara 
rata-rata, Tahun 2012 memiliki nilai availabilitytertinggi dibanding tahun yang lain. Tabel 11 memperlihatkan totaldown timetiap tahunnya.

Tabel 11. Nilai total down time

\begin{tabular}{|c|c|c|c|c|c|c|}
\hline & \multicolumn{6}{|c|}{ Down Time (\%) } \\
\hline & \multicolumn{2}{|c|}{2012} & \multicolumn{2}{|c|}{2013} & \multicolumn{2}{|c|}{2014} \\
\hline & Mesin & Lainnya & Mesin & Lainnya & Mesin & Lainnya \\
\hline Line 1 & 0.20 & 0.70 & 3.61 & 0.11 & 0.41 & 0.13 \\
\hline Line 2 & 0.56 & 2.74 & 4.88 & 1.12 & 0.72 & 0.55 \\
\hline Line 3 & 0.78 & 1.98 & 8.64 & 0.61 & 1.56 & 0.16 \\
\hline Line 6 & 0.43 & 0.91 & 8.11 & 0.46 & 0.66 & 0.12 \\
\hline Line 7 & 0.61 & 1.11 & 5.66 & 0.14 & 1.02 & 0.12 \\
\hline Line 8 & 0.37 & 1.15 & 4.26 & 0.23 & 0.98 & 0.17 \\
\hline Line 9 & 0.67 & 2.01 & 8.22 & 0.43 & 3.21 & 0.24 \\
\hline Rata-rata & 0.52 & 1.51 & 6.20 & 0.44 & 1.22 & 0.21 \\
\hline
\end{tabular}

Sebagaimana Gambar 9 nilai Performance Efficiency, secara umum berada di atas standar global (Nakajima,1988) yaitu 95\%. Performance Efficiency secara umum sangat bagus karena ditunjang oleh actual output yang diatas standar outputpada beberapa lini produksi. Nilai Performance Efficiency terendah tedapat pada tahun 2014 pada lini produksi 3 sebesar $98.04 \%$ (Gambar 4.10).Sedangkan nilai terbesar terdapat pada Tahun 2012 pada lini produksi 1 sebesar 101.29\% (Gambar 4.8).Secara rata-rata, Tahun 2012 memiliki nilai Performance Efficiency tertinggi dibanding tahun yang lain. Nilai Performance Efficiency per tahun diperlihatkan pada Gambar 9,10, 11.

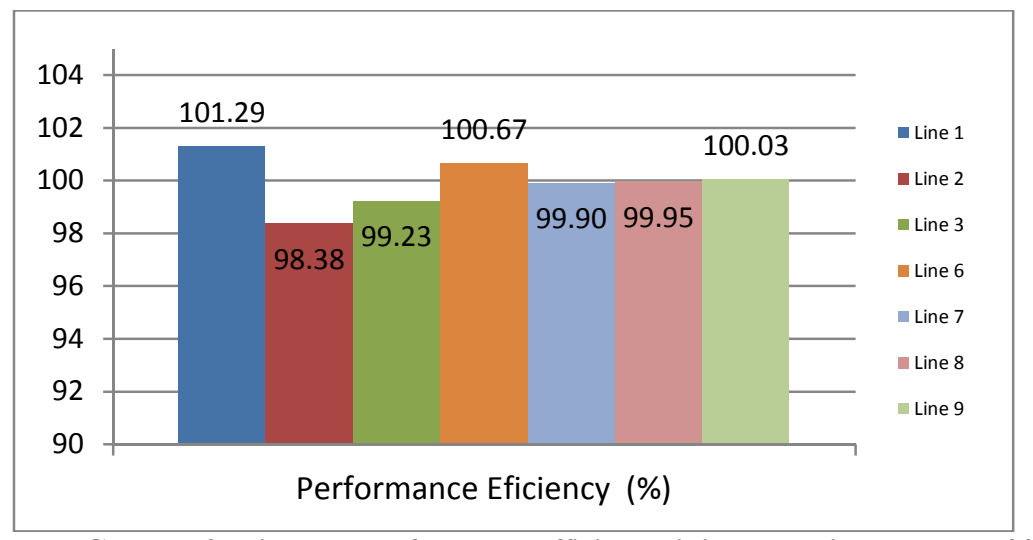

Gambar 9. Diagram performance efficiency lini produksi pada tahun 2012 
21 Muhammad Arsyad, Arthur Halik Razak, Sumardi Mawardi, Fadli Abdul Azis. Analisis Overall Equipment Effectiveness (Oee) Mesin Produksi Pada Pt. Indofood Cbp Sukses Makmur Tbk Makassar

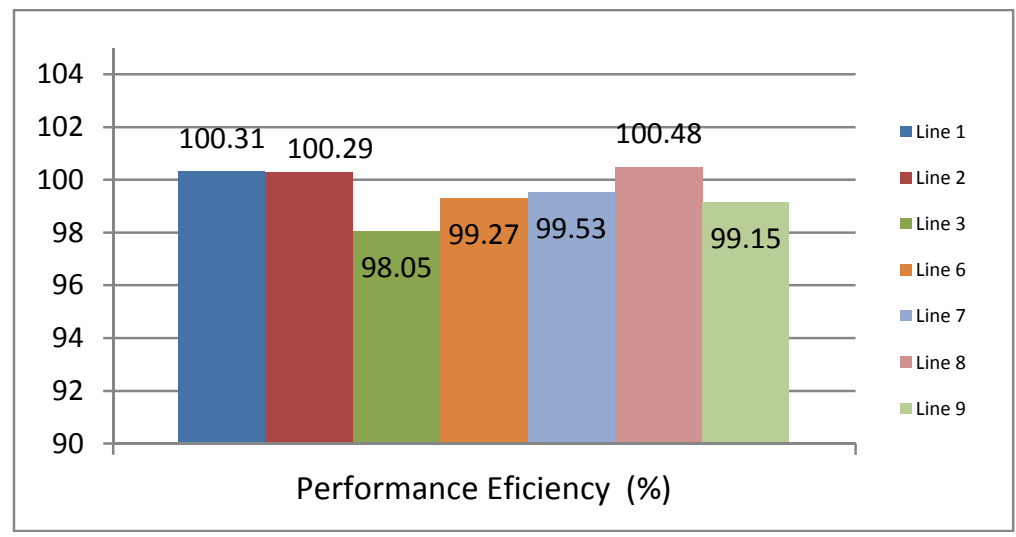

Gambar 10. Diagram performance efficiency lini produksi pada tahun 2013

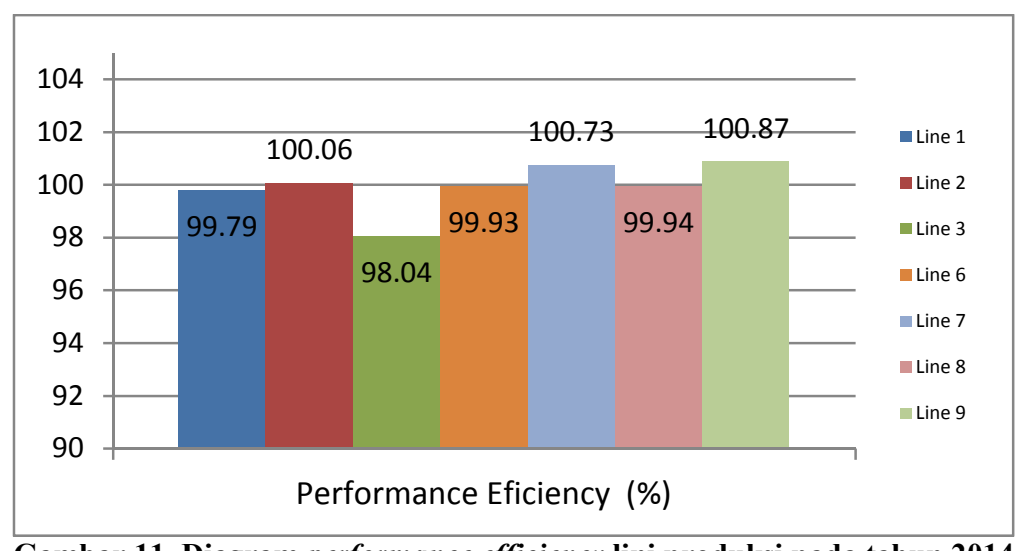

Gambar 11. Diagram performance efficiency lini produksi pada tahun 2014

Dalam perhitungan Rate of Quality, tingginya nilai scrap dari standar yang ditetapkan menurunkan nilai Rate of Quality, hingga nilainya dibawah standar global sebesar 99.9\% (Nakajima,1988). Nilai standar scrap yang diijinkan pada produksi mi instant Indofood adalah sebesar $1 \%$. Jadi, semakin tingggi nilai scrapyang terjadi pada saat proses produksi, maka akan semakin menurunnkan nilai Rate of Quality. Nilai scrapper tahun diperlihatkan pada Tabel 12.

Tabel 12. Nilai scrap 


\begin{tabular}{|c|c|c|c|}
\hline & \multicolumn{3}{|c|}{ Scrap } \\
\hline & \multicolumn{3}{|c|}{$\%$} \\
\hline & 2012 & 2013 & 2014 \\
\hline Line 1 & 1.19 & 0.81 & 2.73 \\
\hline Line 2 & 1.39 & 0.82 & 2.42 \\
\hline Line 3 & 1.42 & 0.85 & 2.55 \\
\hline Line 4 & 0.00 & 0.00 & 0.00 \\
\hline Line 5 & 2.00 & 0.00 & 0.00 \\
\hline Line 6 & 1.15 & 0.87 & 1.54 \\
\hline Line 7 & 1.08 & 0.77 & 1.77 \\
\hline Line 8 & 1.12 & 0.75 & 1.92 \\
\hline Line 10 & 0.00 & 3.05 & 4.36 \\
\hline rata-rata & 1.31 & 1.10 & 2.49 \\
\hline \multicolumn{4}{|c|}{ Standar $=1 \%$ (Sumber $:$ Indofood) } \\
\hline
\end{tabular}

Diantara ketiga tahun yang diteliti, tahun 2013 memiliki nilai scrap yang terendah, sehingga nilai Rate of Qualitydi tahun tersebut pada semua lini yang beroperasi memiliki ratarata yang lebih tinggi dibanding tahun yang lain. Sebaliknya, nilai scrap yang tinggi pada tahun 2014 mengakibatkan nilai rata-rata Rate of Quality tahun 2014 lebih rendah dari tahuntahun yang lain. Grafis nilai Rate of Quality per tahun dapat dilihat sebegai berikut:

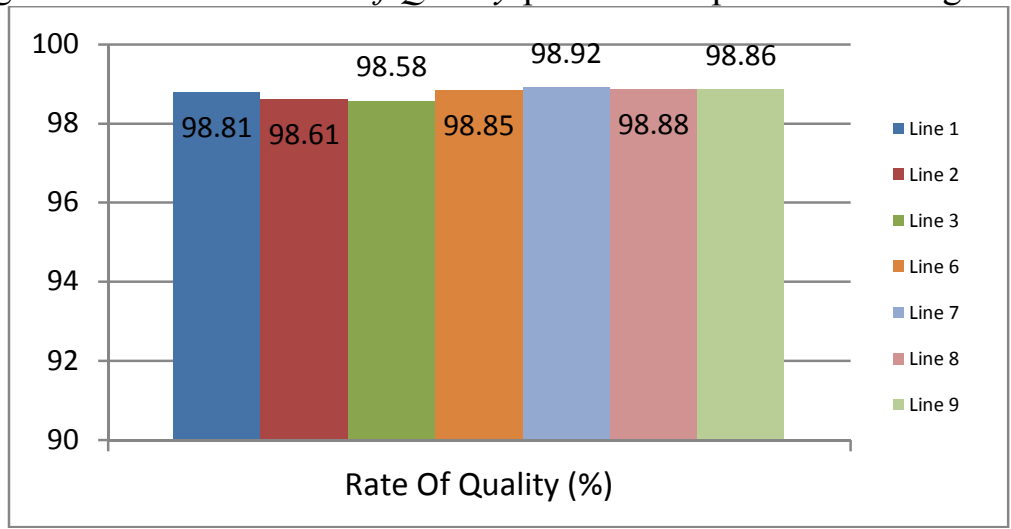

Gambar 12. Diagram Rate of Quality lini produksi pada tahun 2012

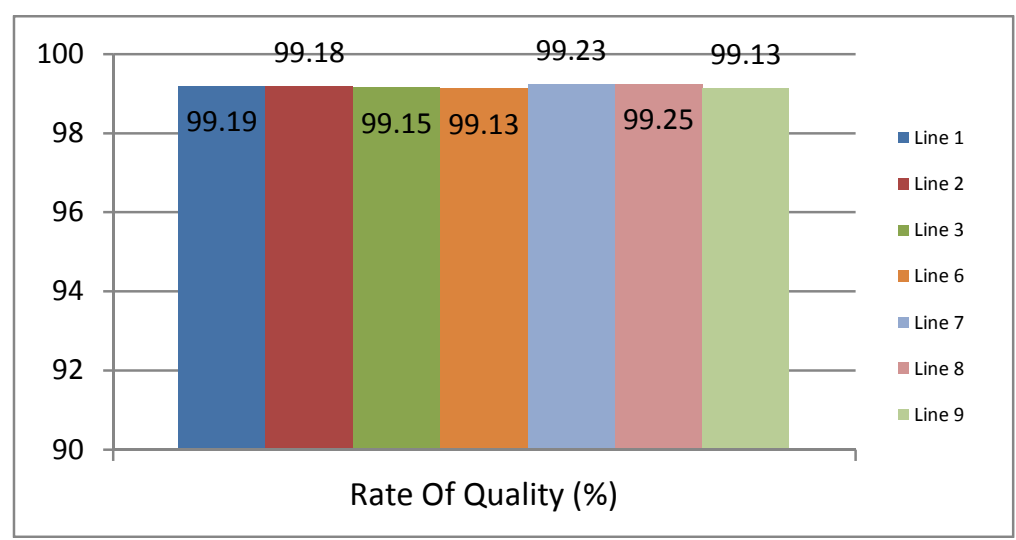

Gambar 13. Diagram Rate of Quality lini produksi pada tahun 2013 
23 Muhammad Arsyad, Arthur Halik Razak, Sumardi Mawardi, Fadli Abdul Azis. Analisis Overall Equipment Effectiveness (Oee) Mesin Produksi Pada Pt. Indofood Cbp Sukses Makmur Tbk Makassar

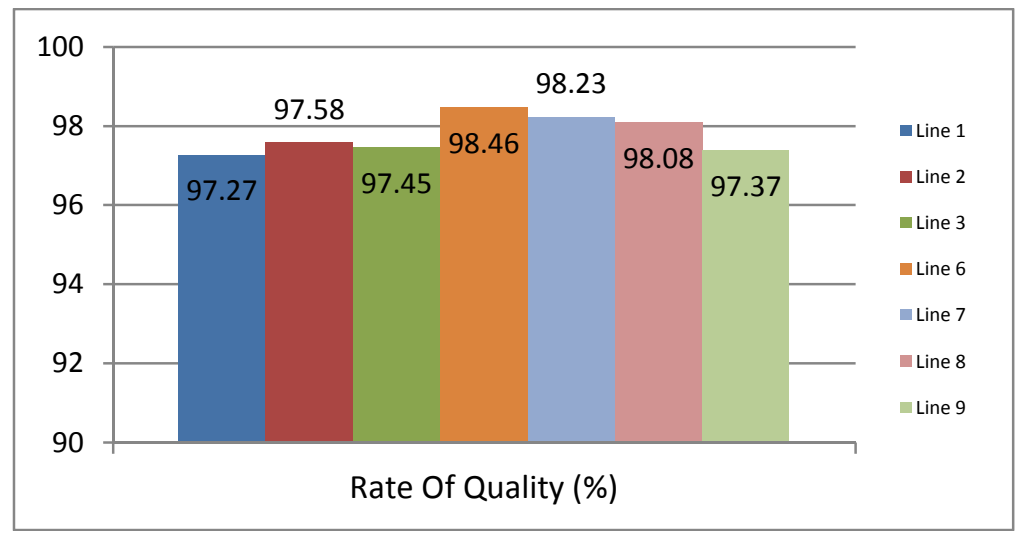

Gambar 14. Diagram Rate of Quality lini produksi pada tahun 2014

Secara keseluruhan nilai OEE setiap lini produksi antara tahun 2012-2014 pada PT. INDOFOOD CBP SUKSES MAKMUR Tbk, Makassar, dapat dikatakan telahmemenuhi standar OEE global yaitu 85\% (Nakajima,1988). Nilai OEE per tahun ditampilkan pada Gambar 15, 16, 17.

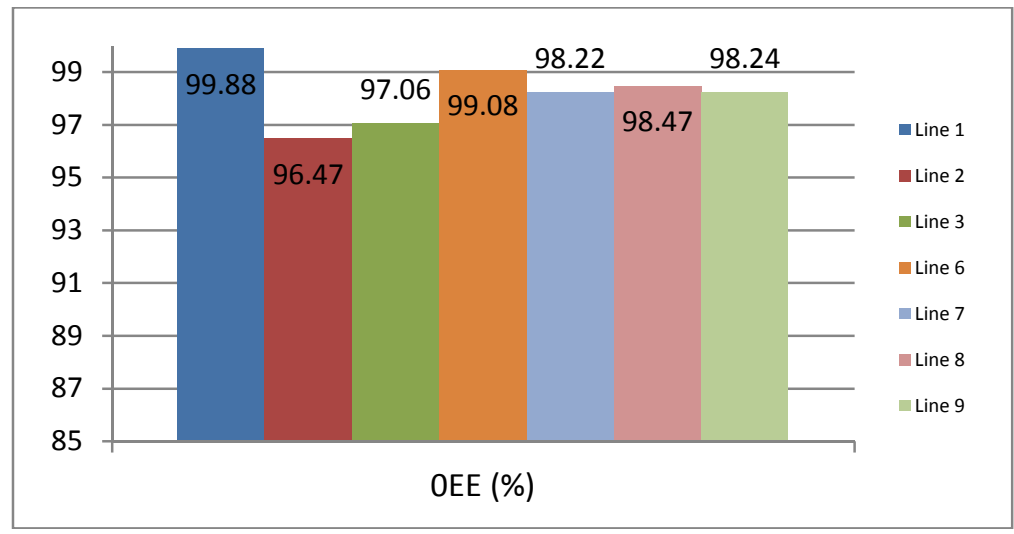

Gambar 15. Diagram OEElini produksi pada tahun 2012

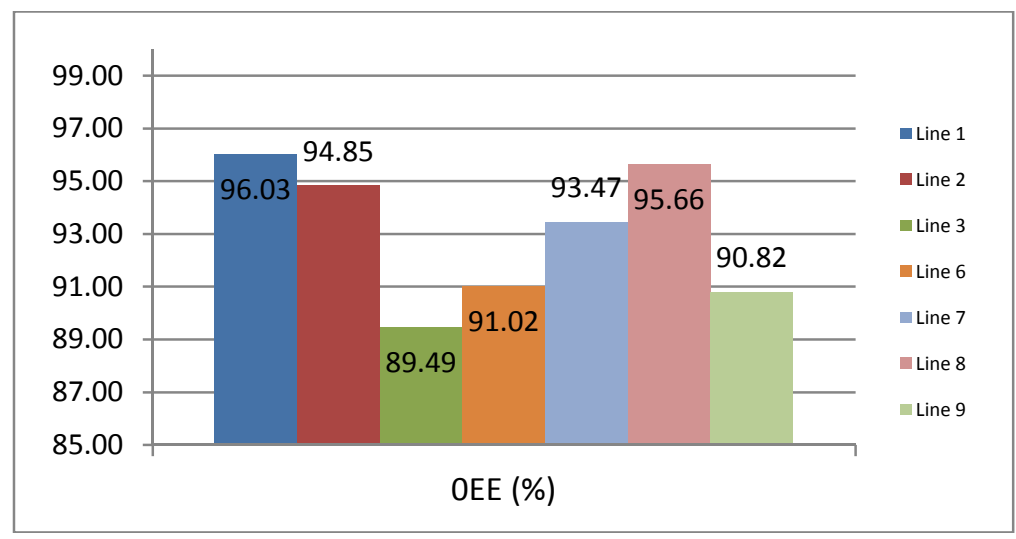

Gambar 16. Diagram OEElini produksi pada tahun 2013 


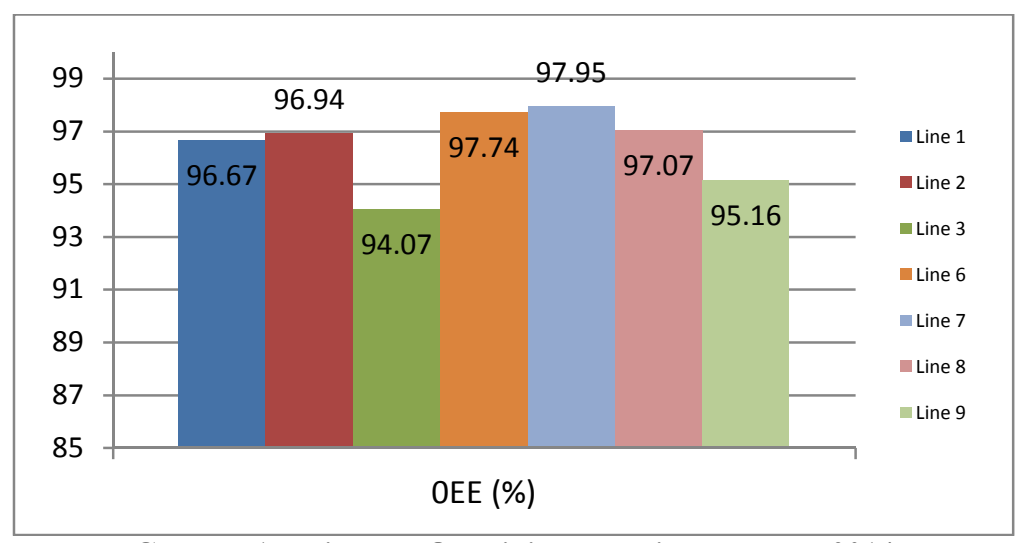

Gambar 17. Diagram OEElini produksi pada tahun 2014

\section{Analisa Six Big Losses}

Seperti yang terlihat pada Gambar 5, Nilai OEE juga ditentukan oleh six big losses. Karena setiap unsur perhitungan OEE, yaitu availability, performance efficiency, dan rate of quality mempunyai unsur pada six big losses. Dari Tabel 4.8, 4.9, 4.10, faktor yang paling banyak mempengaruhi six big lossespada Tahun 2012 adalah idling and minor stoppagesyaitu mencapai 3.83\% pada lini produksi 2 . Hal ini disebabkan oleh besarnya nilai down time lainnya, sebesar $2.74 \%$ (Tabel 12). Terjadinyadown timelainnya terutama disebabkan oleh masalah pada boiler, kontaminasi bau dari luar area produksi, penggantian produk mi, dan habisnya stok air PDAM. Kemudian nilai persentase Equipment failuresyang terbesar terjadi pada lini produksi 2 sebesar 3.28\%. Disebabkan oleh tingginya nilai down time mesin pada tahun itu, lini produksi 2 memiliki down time terbesar diantara lini produksi lainnya pada Tahun 2012. Kemudian nilai yang cukup mempengaruhi adalah scrap loss, dimana pada Tahun 2012 nilai scrappada semua lini produksi melewati standar yang ditentukan sebesar 1\% (Tabel 13). Nilai scrap loss terbesar terjadi pada lini produksi 5 sebesar $1.9 \%$. Nilai reduced speedpada lini produksi 3 mencapai 1.41\%. Tingginya nilai losses pada lini produksi 2 pada Tahun 2012 turut menyebabkan nilai OEE-nya paling rendah pada tahun tersebut (Gambar 15).

Pada Tahun 2013, idling and minor stoppages loss menjadi faktor lossesterbesar dari losses yang ada, kemudian equipment failures. Lini produksi 3 merupakan lini produksi yang nilai mempunyai losses yang paling tinggi secara keseluruhan, hal ini dapat dilihat dari nilai OEE-nya (Gambar 16). Nilai scrap loss pada tahun ini lebih rendah dari tahun yang lainnya.

Sedangkan pada Tahun 2014, lini produksi 9 secara umum memiliki nilai losses yang paling tinggi, namun nilai OEE-nya masih lebih tinggi dari nilai lini produksi 3.

\section{KESIMPULAN}

Penerapan Total Productive Maintenance pada PT. INDOFOOD CBP SUKSES MAKMUR Tbk (divisi noddle - pabrik Makassar) menghasilkan hasil analisa OEE sebagai berikut :

1. Nilai OEE rata-rata per tahun yaitu $98,2 \%$ di Tahun $2012,93,05 \%$ di Tahun 2013 , dan $96,52 \%$ di Tahun 2014. Nilai tersebut telah memenuhi standar yang ditetapkan oleh Nakajima (1988),

2. Faktor yang paling berpengaruh dapat diurutkan dari yang terbesar sebagai berikut:

a. Idling and minor stoppages loss, nilai persentase terbesarnya pada Tahun 2013 di lini produksi 9 sebesar $15,6 \%$.

b. Equipment failures Loss, nilai persentase terbesarnya pada Tahun 2013 di lini produksi 3 sebesar $8,51 \%$.

c. Scrap loss, nilai persentase terbesarnya pada Tahun 2014 di lini produksi 1 sebesar $2,72 \%$.

d. Reduced speed loss, nilai persentase terbesarnya pada Tahun 2014 di lini produksi 3 sebesar $1,96 \%$. 
25 Muhammad Arsyad, Arthur Halik Razak, Sumardi Mawardi, Fadli Abdul Azis. Analisis Overall Equipment Effectiveness (Oee) Mesin Produksi Pada Pt. Indofood Cbp Sukses Makmur Tbk Makassar

e. $\quad$ Setup and adjusment loss, nilai persentase terbesarnya pada Tahun 2013 di lini produksi 9 sebesar $0,79 \%$.

f. Rework loss, nilainya tidak dihitung.

3. Meskipun secara keseluruhan nilai OEE telah memenuhi standar global, tetapi nilai downtime dan nilai scrap rata-rata pertahun masih diatas nilai yang distandarkan oleh Indofood.

\section{DAFTAR PUSTAKA}

Bhadury, B. 2000. Management of productivity through TPM. Productivity, 41(2), 240-51

Cross, J. 1988. Raising the value of maintenance in the corporate environment. Management Research News, 11(3), 8-11.

Dhillon, BS. 2002. Engineering maintenance : a modern approach: CRC Press.

EXOR / DataVisor Marquees. The Complete Guide to Simple OEE. www.exor-rd.com.

Nakajima, S. 1988, Introduction to Total Productive Maintenance, Cambridge, MA, Producticity Press, Inc.

Pintelon, Liliane dan Muchiri, Peter. 2006. Performance measurement using overall equipment effectiveness (OEE) : Literature review and practical application discussion. International Journal of Production Research, hal 1-45.

Http://www.reliabilityweb.com. The History and Impact of Total Productive Maintenance. 